\title{
Relating homology between the Epstein-Barr virus BOLF1 molecule and HLA-DQw8 $\beta$ chain to recent onset Type 1 (insulin-dependent) diabetes mellitus
}

\author{
T. Sairenji ${ }^{1}$, M. Daibata ${ }^{1}$, C.H.Sorli ${ }^{1}$, H. Qvistbäck ${ }_{\circ}^{2}$, R. E. Humphreys ${ }^{1}$, J. Ludvigsson ${ }^{3}$, J.Palmer ${ }^{4}$, \\ M.Landin-Olsson ${ }^{2}$, G. Sundkvist ${ }^{2}$, B. Michelsen ${ }^{5}$, A. Lernmark ${ }^{4}$ and T. Dyrberg ${ }^{5}$ \\ ${ }_{1}$ Departments of Pharmacology and Medicine, University of Massachusetts Medical School, Worcester, Massachusetts, USA \\ ${ }^{2}$ Department of Medicine, University of Lund, Malmö General Hospital, Malmö, Sweden \\ ${ }^{3}$ Department of Pediatrics, University of Linköping, Linköping, Sweden \\ ${ }^{4}$ Department of Medicine, University of Washington Medical School, Seattle Washington, USA \\ ${ }^{5}$ Hagedorn Research Laboratory, Gentofte, Denmark
}

Summary. A role for the Epstein-Barr virus in initiating Type 1 (insulin-dependent) diabetes mellitus has been proposed since Epstein-Barr virus BOLF1(497-513) $A V T P L$ RIFIVPPAAEY has an 11 amino acid identity with HLA-DQw8 3 (49-60) AVTPL GPPAAEY. Rabbit antisera to the BOLF1 (496-515) peptide crossreacted with the homologous DQw8 $\beta$ (44-63) peptide but not with the related DQw7 $\beta(44-63)$ peptide, which differed from the DQw8 peptide only in an ALA to ASP substitution in position 57. Antisera to DQw8 $\beta(49-60)$ reacted with the DQw8 $\beta(44-63)$ peptide and BOLF1 (496-515), but not with DQw7 $\beta$ (44-63). The antiserum to the BOLF1 peptide bound to denatured class II major histocompatibility complex $\beta$ chains from Epstein-Barr virus-transformed DQw8-positive lymphocytes in an immunoblotting analysis. Epstein-Barr virus antibodies were detected at equal frequencies and similar titres in sera of 30 patients with Type 1 diabetes ( 16 of $30 ; 63 \%$ ) and in sera of 20 non-diabetic control subjects ( 13 of $20 ; 65 \%$ ). Sera from diabetic patients did not bind to DQw8 $\beta$ (44-63) or BOLF1(496-515) peptides. From these data we conclude that there is no simple relationship between serological evidence of Epstein-Barr virus infection and crossreactions between homologous Epstein-Barr virus and class II major histocompatibility complex peptides.

Key words: Type 1 (insulin-dependent) diabetes mellitus, molecular mimicry, Epstein-Barr virus, class II MHC molecules, EBV BOLF1
The molecular mimicry hypothesis for the origin of autoimmune disease proposes that sequence homology between a protein of a pathogen and an organ-specific, self protein can trigger an autoimmune response [1]. Evidence for this hypothesis is found in peptide homologies between Klebsiella pneumoniae nitrogenase and HLA-B27 in the case of ankylosing spondylitis [2], and between adenovirus E1B protein and $\alpha$-gliadin in coeliac disease [3]. For Type 1 (insulin-dependent) diabetes mellitus, acute coxsackie virus B4, persistent cytomegalovirus, and rubella virus infections may precede the clinical onset [47], but diabetes-eliciting sequences of these viruses have not been proposed. Environmental factors must contribute to the pathogenesis of Type 1 diabetes, since the concordance rate for the disease in monozygotic twins is about 35\% [8]. Genetics also influence the incidence of the disease, since certain class II major histocompatibility complex (MHC) alleles are closely linked to disease susceptibility [9]. The role of those alleles of class II MHC antigens, especially of HLA-DQ, in the pathogenesis of Type 1 diabetes remains obscure. HLA-DR4 is in linkage disequilibrium with two different alleles of HLA-DQ,
-DQw7, and -DQw8, of which the DQw8 allele is increased among Type 1 diabetic patients [10]. Within the first domain, these two $\beta$-chain alleles differ only by 4 amino acids at positions $13,26,45$, and 57 and it has been suggested that the residue in position 57 may be particularly important $[10,11]$.

Linkages between MHC alleles and diabetes could reflect either MHC restriction of presentation of foreign antigens, and homologous autoantigens, or presentation of a segment of the MHC molecule itself. Homologies between antigens and peptides forming the antigen-binding site (desetope) of class II MHC molecules have been suggested as leading to tolerance [12]. Highly conserved, basic dipeptide sites about the class II MHC desetopes could lead to excision of such segments of those molecules and presentation to the immune system (L.J.Thomas, V.Lam, D. Kostyal, R. E. Humphreys, unpublished observations). In looking for an infectious pathogen which might initiate Type 1 diabetes, Dyrberg et al. found that the Epstein-Barr virus (EBV) BOLF1(497-513) sequence $A V T P L$ RIFIVPPPAAEY is homologous to HLA-DQw8 or $3.2 \beta$ (49-60) AVTPL GPPAAEY [13] 


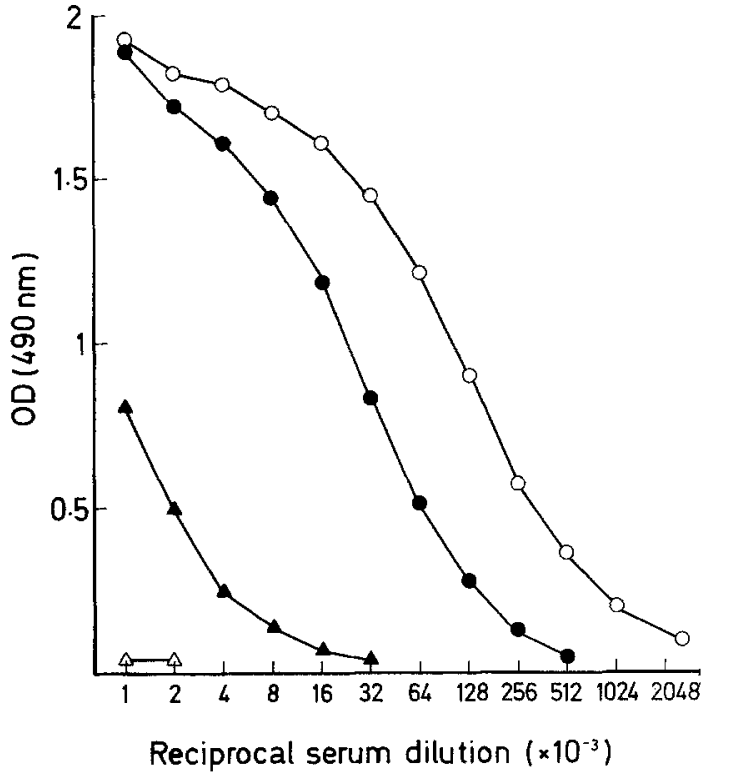

Fig.1. Immunological crossreactivity of antiserum R883 to BOLF1 (496-515) with several peptides. Peptides absorbed to the ELISA plate: $\bigcirc-\mathrm{BOLF1}(496-515), \longrightarrow$ HLA-DQw8 $\beta$ (44-63), $\longrightarrow$ HLA-DQw7 $\beta(44-63), \Delta-\Delta$, irrelevant peptide (papilloma virus E2 $\operatorname{protein}(76-84)$ (CVLHLESLKD))

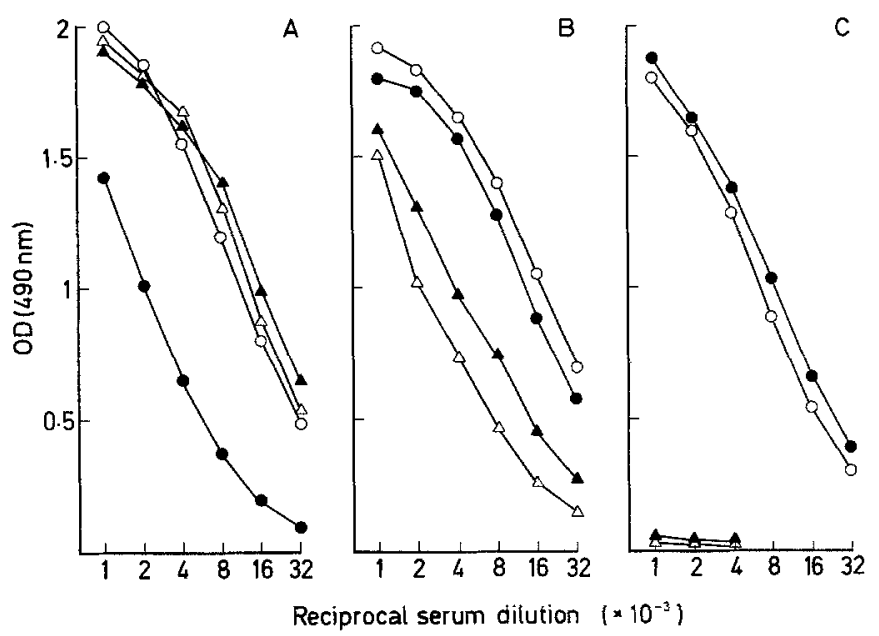

Fig. 2 A-C. Differential binding of rabbit anti-peptide sera to HLADQ $\beta$-chain molecules. Peptides absorbed in ELISA plates: A HLA-DQw7 $\beta$ (44-63); B HLA-DQw8 $\beta$ (44-63); C BOLF1 (496-515). Antisera to: HLA-DQw7 $\beta$ (49-60), $\triangle \triangle \mathrm{R} 1626, \triangleleft$ R1627; HLA-DQw8 $\beta(49-60), \bullet \mathrm{R} 1630, \mathrm{O}-\mathrm{O} 1631$

(Table 1). BOLF1 is a gene for a hypothesized product of unknown function from $\mathrm{BamHI}$ restriction endonuclease fragment $\mathrm{O}$, leftward open reading frame in the B95-8 EBV genome [14]. Furthermore, HLA-DQw8 $\beta$ (53-60) brackets the 57 th residue which is strongly linked to diabetes susceptibility $\left(\mathrm{VAL}^{57}, \mathrm{SER}^{57}, \mathrm{ALA}^{57}\right.$ ) or resistance $\left(\mathrm{ASP}^{57}\right)[10,11]$. That $\mathrm{DQ} \beta$-chain sequence, including the diabetes-resistance-correlated $\mathrm{ASP}^{57}$, is at the end of a helix forming one wall of the antigen-binding site (desetope) [15]. We tested whether serological crossreaction occurred between the homologous sequences of DQw8 $\beta$ and BOLF1, and we analysed sera of recent onset, Type 1 diabetic patients for the presence of EBV antibodies.

\section{Materials and methods}

\section{Peptide syntheses and immunizations}

Peptides were synthesized by a solid-phase method [16] and purified by step gradient elution from a reverse-phase column in $2 \%$ acetic acid with increasing concentrations of acetonitrile. The identity of each peptide was confirmed by analyses of amino acid composition and sequence. Antisera to DQw7 $\beta(49-60)$, DQw $8 \beta(49-60)$ [17] and BOLF1(496-515) were obtained after immunization of rabbits with keyhole limpet haemocyanin-coupled peptides. Peptide-specific antibodies to BOLF1(496-515) were purified by affinity chromatography on peptide-coupled Affi-Gel 10 (BioRad, Richmond, Calif., USA) [18]. The peptide-bound gel was incubated with antiserum, washed with $50 \mathrm{mmol} / 1$ Hepes buffer, $1 \mathrm{mmol} / \mathrm{l} \mathrm{CHAPS}$, pH 7.5, and the specific antibodies were eluted in $1 \mathrm{~mol} / \mathrm{h}$ acetic acid and neutralized.

\section{ELISA}

Microtitre plates were incubated with $5 \mu \mathrm{g} / \mathrm{ml}$ peptide in $50 \mathrm{mmol} / \mathrm{l}$ $\mathrm{Na}_{2} \mathrm{CO}_{3} / \mathrm{NaHCO}_{3}$ buffer, $\mathrm{pH} 9.6$, overnight at room temperature and were washed three times in phosphate-buffered saline solution (PBS) with $0.1 \%$ Tween 20 [19]. The plates were incubated with antisera or sera diluted in PBS containing $1 \% \mathrm{BSA}$ and $0.1 \%$ Tween 20 , at room temperature for $1.5 \mathrm{~h}$, washed and incubated with peroxidase-conjugated $F\left(a b^{\prime}\right)_{2}$ goat-anti-rabbit IgG or goat-antihuman IgG (Zymed, South San Francisco, Calif., USA) for $1.5 \mathrm{~h}$ at room temperature. After washing, substrate $(0.4 \mathrm{mg} / \mathrm{ml} 0$-phenyldiamine and $0.03 \%$ hydrogen peroxide) was added. The reaction was stopped after $30 \mathrm{~min}$ with $2 \mathrm{~mol} / 1 \mathrm{H}_{2} \mathrm{SO}_{4}$ and the absorbance was measured at $490 \mathrm{~nm}$. For competitive ELISA experiments, peptides were added to antisera prior to addition of those mixtures to peptide-coated, microtitre plates [19].

\section{Immunoblotting assays}

EBV-transformed lymphoblasts $\left(10^{7}\right.$ cells) were homogenized in $10 \mathrm{mmol} / \mathrm{l}$ Hepes buffer, $\mathrm{pH} 7.4$, containing $0.25 \mathrm{~mol} / \mathrm{l}$ sucrose, $10 \mathrm{mmol} / \mathrm{l}$ benzamidine, $0.1 \mathrm{mmol} / \mathrm{l}$-chloromercuriphenyl sulfonic acid and $0.5 \%$ (weight/volume) aprotinin, and were centrifuged at $4^{\circ} \mathrm{C}$ for $30 \mathrm{~min}$ at $35000 \times \mathrm{g}$ [17]. The particulate fraction was solubilized for $2 \mathrm{~h}$ at $4{ }^{\circ} \mathrm{C}$ in $10 \mathrm{mmol} / /$ Hepes, $\mathrm{pH} 7.4$, with $150 \mathrm{mmol} / \mathrm{l}$ $\mathrm{NaCl}, 10 \mathrm{mmol} / 1$ benzamidine, $0.63 \%$ (weight/volume) aprotinin and $2 \%$ Triton X-114. The lysate was centrifuged for $15 \mathrm{~min}$ at $4^{\circ} \mathrm{C}$ at $10000 \times g$ to remove nuclei and insoluble particles, and the supernatant was layered on a Hepes buffer with $6 \%$ sucrose [20]. The gradient was incubated at $30^{\circ} \mathrm{C}$ for $5 \mathrm{~min}$, and amphiphilic membrane proteins were obtained by centrifugation at $1500 \times g$ for $3 \mathrm{~min}$ [20]. The detergent-phase proteins were denatured under reducing conditions, subjected to SDS $10 \%$ polyacrylamide gel electrophoresis and electroblotted onto nitrocellulose filters. For immunostaining, nitrocellulose strips were incubated with antisera, washed, incubated with $\mathrm{F}\left(\mathrm{ab}^{\prime}\right)_{2}$ goat-anti-rabbit IgG-alkaline-phosphatase (Zymed), washed, and incubated in substrate buffer $(150 \mathrm{mmol} / \mathrm{l}$ $\mathrm{NaCl}, 5 \mathrm{mmol} / \mathrm{l} \mathrm{MgCl}_{2}, 0.33 \mathrm{mg} / \mathrm{ml}$ nitroblue tetrazolium and $0.17 \mathrm{mg} / \mathrm{ml}$ 5-bromo-4-chloro-3-indolyl phosphate) [17].

\section{Patients and control subjects}

For the first study, sera were obtained from 10 Swedish children who were within 10 days of the diagnosis of Type 1 diabetes and were therapeutically plasmapheresed. Age, sex, and DR histotype are reported in Table 2 for each patient. In the second study, sera were obtained from 20 recent-onset, diabetic Swedish children and from 


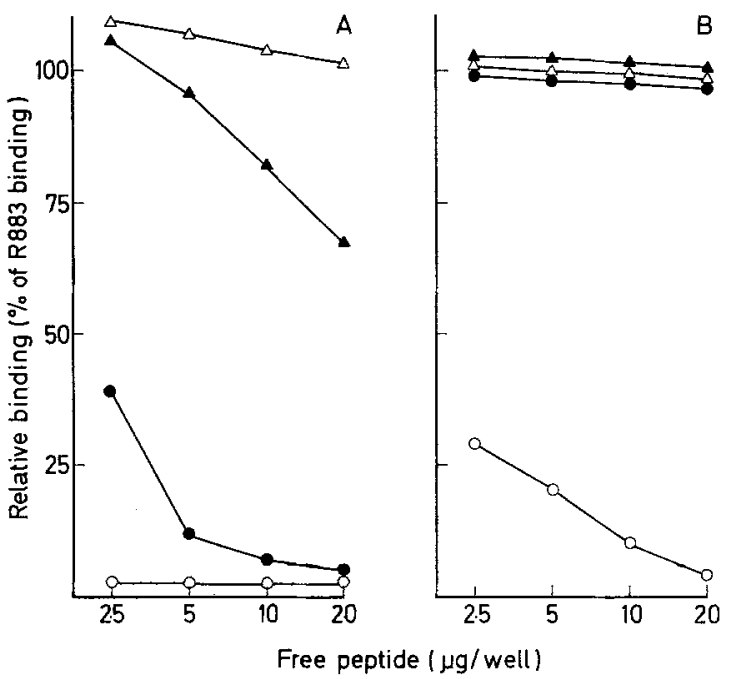

Fig.3 A, B. Binding of anti-BOLF1(496-515) serum R883: competition analysis with free peptides. Peptides absorbed to ELISA plate: A HLA-DQw8 $\beta$ (44-63); B BOLF1(496-515). Competing peptides: $\longrightarrow$ HLA-DQw8 $\beta(44-63)$; $\bigcirc-0$ BOLF1(496-515); HLA-DQw7 $\beta$ (44-63); $\triangle \triangle$ irrelevant peptide (papilloma virus E2 protein $(76-84)$ )

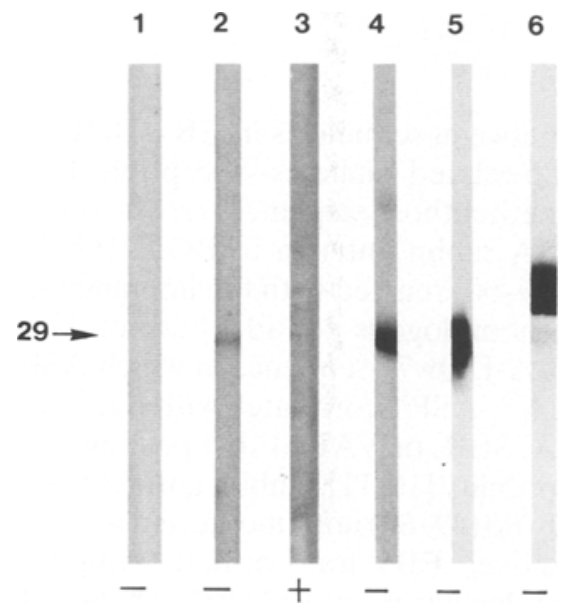

Fig. 4. Immunoblot analysis of EBV-transformed HLA-DQw8positive lymphocytes. Binding of anti-BOLF1(496-515) serum R883 (diluted 1:25) to 29 kilodalton protein. (1) preimmune serum, (2) post-immune serum, (3) post-immune serum with excess of free BOLF1 (496-515) peptide, (4) R1630 antiserum (diluted 1:100) to HLA-DQw8 $\beta$ (49-60), (5) monoclonal antibody to HLA-DR/DQ $\beta$ chains, (6) monoclonal antibody to HLA-DR $\alpha$ chain

20 non-diabetic Swedish children who were matched with the patients for age, sex, and year of presentation. In addition, sera from the following individuals were screened for antibodies to BOLF1 (496-515) and DQw $\beta$ (44-63): 45 patients between 10 and 20 years with Type 1 diabetes with less than 3 months duration of diabetes when the sample was obtained at the Steno Memorial Hospital, Gentofte; 10 adults with Type 1 diabetes of $2-5$ years duration, and 10 adult patients with a disease duration of $8-20$ years and 10 agematched control subjects.

\section{Assays of EBV antibodies}

Antibodies to EBV-associated early antigen (EA) [21,22], viral capsid antigen (VCA) [23], and nuclear antigen (EBNA) [24] were quantitated by indirect immunofluorescence. Fluorescein isothiocyanate (FTTC)-conjugated anti-human IgG or IgM antibodies
(Cappel, Malvern, Penn., USA) were used for the EA and VCA determinations. Antibodies to EBNA were determined by a threestage, anti-complement immunofluorescence assay [25].

\section{Assays for pancreatic islet cell antibodies (ICA) and insulin autoantibodies (IAA)}

Beta cell-specific autoantibodies, ICA, were assayed by a two-colour immunofluorescence technique in which a patient's serum was incubated with slides of human pancreatic tissue in the presence of a monoclonal antibody to proinsulin. FITC-labelled, anti-human IgG and Texas red-labelled, anti-mouse IgG served as second antibodies. ICA titres from serial dilutions of the sera were converted to Juvenile Diabetes Foundation (JDF) units with a standard curve generated from the JDF International reference sera [26, 27]. IAA was determined in a radioligand binding assay [28]. The BOLF1 (496-515) peptide was ${ }^{125}$-labelled by the chloramine-T method [29] and separated from free iodide by step gradient elution from a reverse phase column. Serum was incubated for $60 \mathrm{~min}$ at $4^{\circ} \mathrm{C}$ with ${ }^{125} \mathrm{I}-\mathrm{BOLF1}(496-515)$ at $250000 \mathrm{cpm} / \mathrm{sample}$ in a final volume of $150 \mu \mathrm{l}$. That mixture was incubated for $30 \mathrm{~min} 4^{\circ} \mathrm{C}$ with protein ASepharose, $5 \mathrm{mg} / \mathrm{sample}$, and immune complexes were isolated by centrifugation, washed twice, and the precipitated radioactivity was counted.

\section{Results}

In a comparison of the sequence of HLA-DQw $8 \beta$ to proteins of the Protein Identification Resource [30], a region was found with 11 of 17 residues shared with an EBV protein, BOLF1 [13], (Table 1). To determine whether these sequences crossreacted serologically, antisera to each peptide were tested by ELISA methods. Anti-BOLF1 (496-515) bound to the BOLF1 and DQw8 $\beta(44-63)$ peptides with a high titre, but to the $\mathrm{DQw} 7 \beta(44-63)$ peptide with a much lower titer, and not at all to an irrelevant peptide, papilloma virus, E2 protein (76-84) (Fig. 1). Antisera to DQw8 $\beta$ (49-60) bound DQw7 $\beta$ (44-63) (A), DQw8 $\beta$ (44-63) (B), and BOLF1(496-515) (C) (Fig.2). In contrast, antisera to $\mathrm{DQw} 7 \beta(49-60)$ bound the $\mathrm{DQw} 7 \beta(44-$ 63 ) and DQw8 $\beta$ (44-63) peptides, but not the BOLF1 (496-515) peptide. The binding of the BOLF1 antisera to DQw8 $\beta$ (44-63) was inhibited by DQw8 $\beta(44-63)$ and by the BOLF1 peptide, but not by the $\mathrm{DQw} 7 \beta$ or the irrelevant papilloma virus peptide (Fig.3). The binding of antiBOLF1 serum to BOLF1(496-515) was inhibited by the BOLF1 peptide, only. Affinity-purified antibodies to BOLF1(496-515) showed the same binding characteristics as did the antiserum (data not shown).

Antisera from three of the four rabbits immunized with the BOLF1 peptide immunoblotted to a 29 kilodalton $(\mathrm{kd})$ protein, presumably the class II MHC $\beta$ chain, from HLA-DQw8-positive, transformed lymphoblasts (Fig. 4). The binding to the $29 \mathrm{kd}$ protein, was inhibited by BOLF1(496-515) or DQw8 $\beta$ (44-63) peptides, but only partly by DQw7 $\beta$ (44-63) or the irrelevant papilloma virus peptide. Similarly, affinity-purified antibodies to the BOLF1 peptide showed specific binding to the $29 \mathrm{kd}$ protein in immunoblotting analysis (data not shown).

In order to determine whether recently diagnosed Type 1 diabetic patients had been infected with EBV, we tested sera from 10 children treated with plasmapheresis 


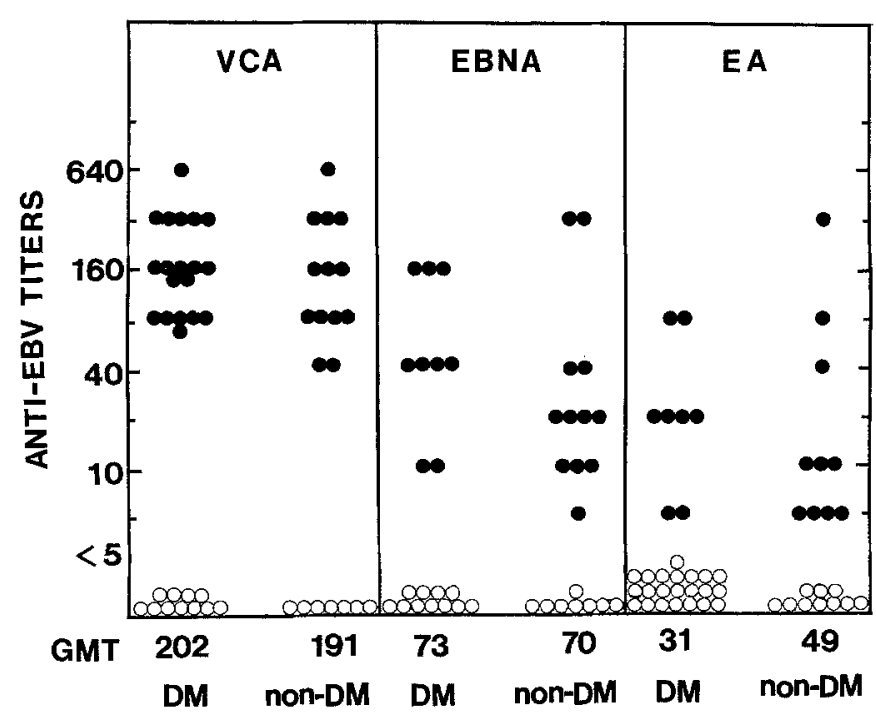

Fig.5. Epstein-Barr virus (EBV) antibodies in patients' sera with or without Type 1 (insulin-dependent) diabetes mellitus. DM, Type 1 diabetes mellitus (insulin-dependent); non-DM, control; GMT, geometric mean titre; VCA - viral capsid antigen; EBNA - EBV nuclear antigen; EA - early antigen

at the time of clinical onset. These sera (Nos.1-10 of Table 2) each contained EBV antibodies, as shown in IgG VCA titres ranging from 1:80 to 1:640. Since IgM antiVCA antibodies, which are detected in acute stages of the infection, were not detected, the patients were considered to have past, but not acute or early convalescent phase infections as seen in the course of infectious mononucleosis [31]. An IgG anti-EA titre $\geq 1: 20$ was detected in only sera of patients with acute or chronic EBV infection [31]. One serum (No. 8) had abnormally high titres to VCA and $\mathrm{EA}$, indicating a late stage of acute infection or a chronic infection.

In light of the concordance between EBV infection and diabetic status in these 10 patients, additional sera from diabetic patients and control subjects were tested (Nos. 11-50 of Table 2). EBV antibodies to both VCA and EBNA were detected, respectively, in 9 of 20 and 12 of 20 sera of the patients and control subjects. Anti-EA antibodies $(\geq 1: 20)$ were detected in 6 of $30(20 \%)$ or 3 of 20 $(15 \%)$ of the patients and control subjekts, respectively (Table 2 and Fig.5). These anti-EA-positive individuals (No. 8, 15, 24, 27, 30, 34, 36, 38, and 39) must have had acute or chronic EBV infections, but no IgM anti-VCA antibody was detected (Table 2). There was no correlation between diabetic status and infection with EBV (Fig.5). Also, among diabetic patients with EBV antibodies, there was no correlation between ICA and EBV antibodies (Table 2).

The presence of anti-BOLF1(496-513) antibodies in sera of diabetic patients was tested for by an ELISA. The binding to BOLF1(496-515) and DQw $\beta \beta(44-63)$ induced by sera at a final dilution of $1: 24$, from 10 diabetic patients with a disease duration of 2 to 5 years (absorbance at $492 \mathrm{~nm}$, mean \pm SD: $0.076 \pm 0.038$ and $0.071 \pm 0.037$ ) and from 10 patients with 8 to 20 years disease duration $(0.061 \pm 0.019$ and $0.059 \pm 0.016$ respectively) was not different from that induced by 10 control sera to the same
Table 1. Homologous amino acid sequences between an EpsteinBarr virus BOLF1 and HLA-DQ $\beta$-chain molecules

\begin{tabular}{lcl}
\hline Protein & Residues & Amino acids \\
\hline EBV BOLF1 & $496-516$ & DAVTPLRIFIVPPPAA EYEOV \\
HLA-DQw8 & $43-63$ & DVGVYRAVTPLGPPAAEYWN \\
$\beta$ chain & & \\
HLA-DQw7 & $43-63$ & DVEVYRAVTPLGPPDAEYWNS \\
$\beta$ chain & & \\
\hline
\end{tabular}

peptides $(0.107 \pm 0.067$ and $0.066 \pm 0.042$, respectively) or to uncoated ELISA plates $(0.091 \pm 0.056)$. The sera of 45 recent onset diabetic children were also tested for binding to ${ }^{125} \mathrm{I}-\mathrm{BOLF} 1(496-515)$ in a radioligand assay. At a final serum dilution of $1: 25$ the mean binding $(275 \pm 22 \mathrm{cpm})$ was not different from the non-specific binding of the radiolabelled peptide to protein A-Sepharose $(276 \pm 10 \mathrm{cpm})$. In contrast, rabbit antiserum to BOLF1(496-515) at a final dilution of 1:1000 bound the radiolabelled peptide $(35,219 \mathrm{cpm})$. This binding was specific since incubation with an excess of unlabelled BOLF1(496-515) reduced to $195 \mathrm{cpm}$.

\section{Discussion}

Finding a homology between sequences in EBV BOLF1 and the HLA-DQw8 $\beta$-related diabetes-susceptible DQ allele, led us to test whether those sequences crossreacted serologically. In ELISA rabbit antisera to BOLF1(496$515)$ and to DQw $8 \beta(49-60)$ reacted with the immunizing peptide and with the homologous peptide, but not with the closely related HLA-DQw $7 \beta$ sequence in which ASP is substituted for $\mathrm{ALA}^{57}$. $\mathrm{ASP}^{57}$ correlates with diabetes resistance, while ALA, SER, or VAL at that position relate to diabetes susceptibility $[10,11]$. Rabbit anti-BOLF1 (496-515) or anti-DQw8 $\beta(49-60)$ immunoblotted to a denatured $\mathrm{DQw} 8 \beta$-positive, EBV-transformed, lymphoblast protein of the molecular weight $(29 \mathrm{kD})$ of class II MHC $\beta$ chain. There was no evidence for recognition of native class II MHC $\beta$ chains by anti-BOLF1(496-515) in immunofluorescence or immunoprecipitation assays. Also, antibodies to DQw8 $\beta$ (44-63) or BOLF1(496-515) peptides were not detected in sera of patients with acute onset or long-term Type 1 diabetes. These studies demonstrated clearly the potential for immunological recognition of sequence homology and discrimination of the ALA $\rightarrow$ ASP substitution in position 57. Homologous sequences have been found in class II MHC $\beta$ chains and some viruses which infect humans. The IE- 2 region of cytomegalovirus shares a five amino acid segment with a conserved region of the first domain of HLA-DR $\beta$-chain, showing immunological crossreactivity [32]. This homology might enhance graft rejection when cytomegalovirus infection follows organ transplantation. Other homologies between rubella virus [33] and EBV [34, 35], and HLA-DR and -DQ $\beta$-chain sequences have been suggested to lead to Type 1 diabetes and rheumatoid arthritis, respectively. Human immunodeficiency virus (HIV) gp41 (838-844) shares 4 of 6 amino acids with HLA-DR(19$25)$ and HLA-DQ $\beta(19-25)$ [36]. Since antibodies from 
Table 2. Epstein-Barr virus (EBV) antibodies in subjects with and without newly diagnosed, Type (insulin-dependent) diabetes mellitus

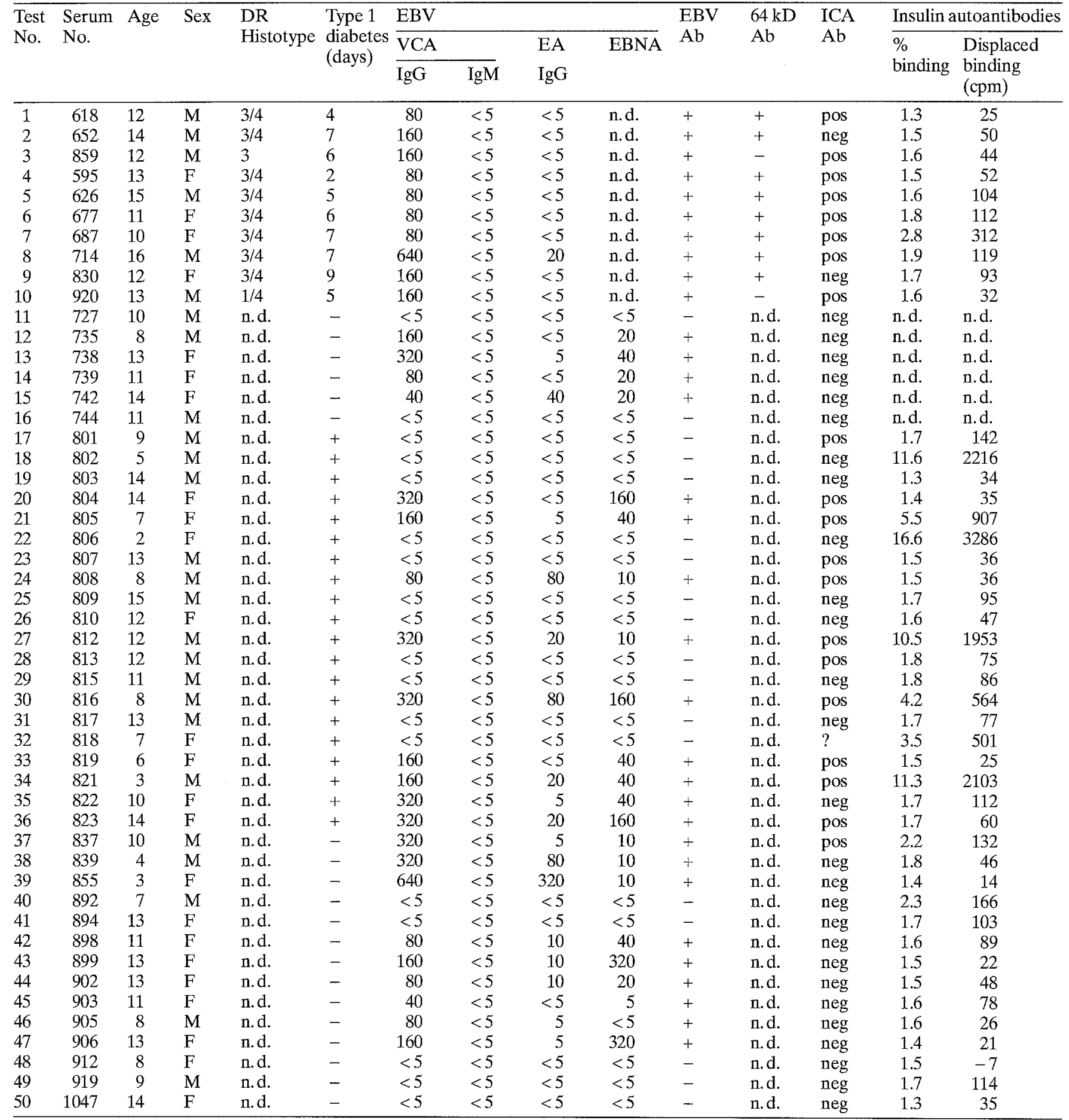

n. d. = not determined; VCA = viral capsid antigen; EBNA = nuclear antigen

some patients with AIDS reacted with the class II MHC $\beta$ peptide and intact class II MHC molecules, the reaction of anti-HIV antibodies with self class II MHC antigens was proposed to alter class II MHC-mediated immune responses, contributing to immunodeficiency [36, 37]. Proliferative responses of normal $\mathrm{CD} 4{ }^{+} \mathrm{T}$ cells to tetanus toxoid and alloantigens were inhibited by antisera to class II MHC molecules [37]. In our study, diabetic patients did not demonstrate antibodies to the unfolded peptides or denatured, electrophoresed class II MHC $\beta$ chain mole- cules. The lack of such serological recognition of denatured determinants did not exclude serological recognition of native determinants, or of excised fragments by $\mathrm{T}$ cells.

If EBV were the principal, predisposing pathogen for Type 1 diabetes, as one might suppose from our serological study of the homologous epitopes in EBV BOLF1 and some class II MHC $\beta$ chains, then one might expect increased titres of anti-EBV antibodies in the sera of patients with acute onset, Type 1 diabetes. We therefore as- 
sayed sera from 10 children with acute onset Type 1 diabetes at the onset of their disease. All of those patients had EBV antibodies. We extended this study to coded samples of 20 additional patients at the onset of diabetes and 20 age- and sex-matched children without diabetes. These latter 40 sera demonstrated no correlation between EBV infection and diabetes. The failure to relate serological evidence of EBV to Type 1 diabetes indicates that there is no simple relationship between EBV infections and the homologies and crossreactions which exist between some EBV proteins and class II MHC molecules. Further studies of concident cases and matched control subjects from one geographical area might be required to disprove, conclusively at an epidemiological level, the hypothesis that EBV infection is causally related to Type 1 diabetes. Furthermore, studies of $T$ cell reactivity might reveal immunogenic determinants not seen with sera, or more sensitive serological measurements, perhaps for additional determinants might be required.

Acknowledgments. This work was supported by an institutional Diabetes Endocrinology Research Center Grant DK 32520 of the University of Massachusetts Medical School (to R.E.H.), by National Institutes of Health grants AI 23061 (to T.S.) and CA 37645 (to. R.E.H.), and by grants from the Swedish Medical Research Council (19I-07 507), the Lundström Foundation, and the Swedish Life Assurance Company Fund (to G. S.). C.S. was a predoctoral fellow of the Howard Hughes Medical Institute. H. Q. was a fellow of the Juvenile Diabetes Foundation International summer research program. T.D. was the recipient of a Career Development Award from the Juvenile Diabetes Foundation International. M. L-O. was a postdoctoral fellow of the Juvenile Diabetes Foundation International. We thank Ms. M.Bonin and P. Downe for assistance in the preparation of this manuscript.

\section{References}

1. Oldstone MBA (1987) Molecular mimicry and autoimmune disease. Cell 50: 819-820

2. Schwimmbeck PL, Yu DTY, Oldstone MBA (1987) Autoantibodies to HLA B27 in the sera of HLA B27 patients with ankylosing spondylitis and Reiter's syndrome: molecular mimicry with Klebsiella pneumoniae as potential mechanism of autoimmune disease. J Exp Med 166: 173-181

3. Kagnoff MF, Austin RK, Hubert JJ, Bernardin JE, Kasarda DD (1984) Possible role for a human adenovirus in the pathogenesis of celiac disease. J Exp Med 160: 1544-1557

4. Yoon J-W, Austin M, Onodera T, Notkins AL (1979) Virus-induced diabetes mellitus. Isolation of a virus from the pancreas of a child with diabetic ketoacidosis. New Engl J Med 300: 11731179

5. Notkins AL, Yoon J (1984) Virus-induced diabetes mellitus. In: Notkins AL, Oldstone MBA (eds) Concepts in viral pathogenesis. Springer, Berlin Heidelberg New York, pp 241-247

6. Pak CY, Eun HM, McArthur RG, Yoon JW (1988) Association of cytomegalovirus infection with autoimmune Type 1 diabetes. Lancet II: $1-4$

7. Ginsberg-Fellner F, Witt ME, Fedun B, Taub F, Dobersen MJ, McEvoy RC, Cooper LZ, Notkins AL, Rubinstein P (1985) Diabetes mellitus and autoimmunity in patients with congenital rubella syndrome. Rev Infect Dis 7 [Suppl 1]: S170-175

8. Olmos P, A'Hern R, Heaton DA, Millward BA, Risley D, Pyke DA, Leslie RDG (1988) The significance of the concordance rate for Type 1 (insulin-dependent) diabetes in identical twins. Diabetologia 31 : $747-750$
9. Platz P, Jakobsen BK, Morling N, Ryder LP, Svejgaard A, Thomsen M, Christy M, Kromann H, Benn J, Green A, Hauge M (1981) HLA-D and -DR antigens in genetic analysis of insulindependent diabetes mellitus. Diabetologia 21:108-115

10. Todd JA, Bell JI, McDevitt HO (1987) HLA-DQ $\beta$ gene contributes to susceptibility and resistance to insulin-dependent diabetes mellitus. Nature 329: 599-604

11. Todd JA, Acha-Orbea H, Bell JI, Chao N, Fronek Z, Jacob CO, McDermott M, Sinha AA, Timmerman L, Steinman L, McDevitt HO (1988) A molecular basis for MHC class II-associated autoimmunity. Science 240: 1003-1009

12. Guillet JG, Lai MZ, Briner TJ, Buus S, Sette A, Grey HM, Smith JA, Gefter ML (1987) Immunological self, nonself discrimination. Science 235: $865-870$

13. Dyrberg T, Michelsen B, Oldstone MBA (1988) Virus and host cell antigen sharing in myasthenia gravis and autoimmune diabetes. In: Lernmark $\AA$, Dyrberg T, Terenius L, Hökfelt B (eds) Molecular mimicry in health and disease, International Congress Series 823. Elsevier, Amsterdam, pp 245-254

14. Baer R, Banker AT, Biggin MD, Deininger PL, Farrell PJ, Gibson TJ, Hatfull G, Hudson GS, Satchwell SC, Séguin C, Tuffnell PS, Barrell BG (1984) DNA sequence and expression of the B958 Epstein-Barr virus genome. Nature 310: 207-211

15. Brown JH, Jardetzky T, Saper MA, Samraoui B, Bjorkman PJ, Wiley DC (1988) A hypothetical model of the foreign antigen binding site of class II histocompatibility molecules. Nature 332 : $845-850$

16. Stewart JM, Young JD (1984) Solid phase peptide synthesis. Pierce Chemical Company, Rockford, IL, pp 1-49

17. Atar D, Dyrberg T, Michelsen B, Karlsen A, Kofod H, Mølvig J, Lernmark $\AA$ (1989) Site-specific antibodies distinguish single amino acid substitutions in position 57 in HLA-DQ $\beta$-chain alIeles associated with insulin-dependent diabetes. J Immunol 143: 533-538

18. Vaughan JM, Rivier J, Corrigan AZ, McClintock R, Campen CA, Jolley D, Vogelmayr JK, Bardin CW, Rivier C, Vale W (1989) Detection and purification of inhibin using antisera generated against synthetic peptide fragments. In: Conn PM (ed) Methods in Enzymology (Hormone Action, Part L: Neuroendocrine Peptides). Academic Press, Orlando, 168: 588-617

19. Dyrberg T, Petersen JS, Oldstone MBA (1990) Immunological cross-reactivity between mimicking epitopes on a virus protein and a human autoantigen depends on a single amino acid residue. Clin Immunol Immunopathol 54: 290-297

20. Bordier C (1981) Phase separation of integral membrane proteins in triton X-114 solution. J Biol Chem 256: 1604-1607

21. Henle W, Henle G, Zajac BA, Pearson G, Waubke R, Scriba M (1970) Differential reactivity of human serums with early antigens induced by Epstein-Barr virus. Science 169: 188-190

22. Hinuma Y, Sairenji T, Ohta-Hatano R (1970) Detection of antibody to a new antigen induced by Epstein-Barr virus in serum from patients with malignant lymphoid diseases. Proc Jap Acad 46: $989-992$

23. Henle G, Henle W (1966) Immunofluorescence in cells derived from Burkitt lymphoma. J Bacteriol 91: 1248-1256

24. Reedman BM, Klein G (1973) Cellular localization of an Epstein-Barr virus (EBV)-associated complement-fixing antigen in producer and non-producer lymphoblastoid cell lines. Int $J$ Cancer 11: 499-520

25. Henle W, Guerra A, Henle G (1974) False negative and prozone reactions in tests for antibodies to Epstein-Barr virus-associated nuclear antigen. Int J Cancer 13: 751-754

26. Landin-Olsson M, Sundkvist G, Lernmark $\AA$ (1987) Prolonged incubation in the two-colour immunofluorescence test increases the prevalence and titres of islet cell antibodies in Type 1 (insulin-dependent) diabetes mellitus. Diabetologia 30: 327-332

27. Bonifacio E, Lernmark $\AA$, Dawkins RL, Arnaiz-Villena A, Barbosa J, Betterle C, Boehm B, Boitard C, Bottazzo GF, Bright GM, Chapel H, Di Mario U, Eisenbarth GS, Elliot RB, Gerbitz K, Gleichman H, Harrison L, Helmke K, Hulinsky I, Kobayashi 
T, Kumar WJ, Landin M, Molenaar JI, Palmer JB, Peter JB, Reinauer KM, Scott RS, Scott-Morgan L (1988) Serum exchange and use of dilutions have improved precision of measurement of islet cell antibodies. J Immunol Methods 106: 83-88

28. Palmer JP, Asplin CM, Clemons P, Lyen K, Tatpati O, Raghu PK, Paquette TL (1983) Insulin antibodies in insulin-dependent diabetics before insulin treatment. Science 222: 1337

29. Dyrberg T, Billestrup N (1984) Preparation of ${ }^{125}$ I-protein A useful for up to 10 months in immunoassay procedures. Immunol Methods 71: 193-201

30. George DG, Barker WC, Hunt LT (1986) The protein identification resource (PIR). Nucleic Acids Res 14: 11-15

31. Henle W, Henle G, Horwitz CA (1974) The Epstein-Barr virus specific diagnostic tests in infections mononucleosis. Human Pathol 5: 551-565

32. Fujinami RS, Nelson JA, Walker L, Oldstone MBA (1988) Sequence homology and imunologic cross-reactivity of human cytomegalovirus with HLA-DR $\beta$ chain: a means for graft rejection and immunosuppression. J Virol 62: 100-105

33. Horn GT, Bugawan TL, Long CM, Erlich HA (1988) Allelic sequence variation of the HLA-DQ loci: relationship to serology and to insulin-dependent diabetes susceptibility. Proc Natl Acad Sci USA 85: 6012-6016

34. Roudier J, Petersen J, Rhodes GH, Luka J, Carson DA (1989) Susceptibility to rheumatoid arthritis maps to a T-cell epitope shared by the HLA-Dw4 DR $\beta-1$ chain and the Epstein-Barr virus glycoprotein gp110. Proc Natl Acad Sci USA 86:5104-5108
35. Roudier J, Rhodes G, Petersen J, Vaughan JH, Carson DA (1988) The Epstein-Barr virus glycoprotein gp110, a molecular link between HLA DR4, HLA DR1, and rheumatoid arthritis. Scand J Immunol 27: 367-371

36. Golding H, Robery FA, Gates FT, Linder W, Reining PR, Hoffman T, Golding B (1988) Identification of homologous regious in human inmunodeficiency virus I gp 41 and human MHC class II $\beta 1$ domain. J Exp Med 167: 914-923

37. Golding $H$, Shearer GM, Hillman $K$, Lucas $P$, Manischewitz J, Zajac RA, Clerici M, Gress RE, Boswell RN, Golding B (1989) Common epitope in human immunodeficiency virus (HIV) 1 GP41 and HLA class II elicits immunosuppressive autoantibodies capable of contributing to immune dysfunction in HIV Iinfected individuals. J Clin Invest 83: 1430-1435

Received: 14 March 1990

and in revised form: 6 July 1990

Dr. T. Sairenji

Department of Pharmacology

University of Massachusetts Medical School

55 Lake Avenue, North

Worcester, MA 01655

USA 